\title{
Reduced Extracellular pH Increases Endothelin-1 Secretion by Human Renal Microvascular Endothelial Cells
}

\author{
Donald E. Wesson, Jan Simoni, and Dollie F. Green \\ Department of Internal Medicine, Department of Surgery, and Department of Physiology, Texas Tech University Health Sciences Center, \\ Lubbock, Texas 79430; and Department of Internal Medicine, University of Miami School of Medicine, Miami, Florida 33136
}

\begin{abstract}
Because dietary acid increases renal secretion of endothelin-1 (ET-1) which is synthesized by renal microvascular endothelium, we examined if reduced extracellular $\mathrm{pH}$ increases ET-1 secretion by cultured human renal microvascular endothelial cells (RMVECs). Confluent cells were exposed to serum-free media for $24 \mathrm{~h}$, then incubated in either control, acid, or alkaline serum-free media for $12 \mathrm{~h}$. Standard growth media pH was 7.2 after equilibration with $5 \% \mathrm{CO}_{2}$ at $37^{\circ} \mathrm{C}$ and was made the $\mathrm{pH}$ of control media. Acid and alkaline media $\mathrm{pH}$ were 7.0 and 7.4, respectively. Added Hepes and Tris maintained all assigned pHs. Media ET-1 measured by RIA after column extraction was higher for RMVECs exposed to acid compared with control media $(\mathbf{1 7 0 . 0} \pm 17.1$ vs. $64.6 \pm 9.6 \mathrm{pM}, P<0.004)$ but those exposed to alkaline media $(56.6 \pm 25.1 \mathrm{pM}, P=\mathrm{NS}$ vs. control) were not. Human aortic endothelial cells exposed to control, acid, and alkaline media had similar ET-1 (166.6 \pm 18.1 , 139.3 \pm 18.5 , and 205.9 $\pm 25.3 \mathrm{pM}, P=\mathrm{NS})$. The data show acid-stimulated ET-1 secretion by RMVECs but not aortic endothelial cells, demonstrating a new environmental factor that influences ET-1 secretion by renal microvascular endothelium and thereby possibly modulates endothelindependent processes in vivo. (J. Clin. Invest. 1998. 101:578583.) Key words: acid • aortic endothelial cells • glomerular endothelial cells $\bullet$ kidney
\end{abstract}

\section{Introduction}

Dietary acid increases endothelin-1 (ET-1) ${ }^{1}$ addition to renal cortical interstitial fluid (1), but how this maneuver increases renal cortical ET-1 content is unknown. Dietary acid also increases renal cortical acid content (2), raising the possibility that this change might mediate increased renal cortical ET-1 levels. Cortical renal microvascular endothelial cells (RM-

Address correspondence to Donald E. Wesson, M.D., Texas Tech University Health Sciences Center, Renal Section, 3601 Fourth Street, Lubbock, TX 79430. Phone: 806-743-3155; FAX: 806-7433148; E-mail: Phydew@TTUHSC.edu

Received for publication 9 June 1997 and accepted in revised form 24 November 1997.

1. Abbreviations used in this paper: AEC, aortic endothelial cell; EGM, endothelial growth media; ET-1, endothelin-1; RMVEC, renal microvascular endothelial cell.

J. Clin. Invest.

(C) The American Society for Clinical Investigation, Inc. 0021-9738/98/02/0578/06 \$2.00

Volume 101, Number 3, February 1998, 578-583

http://www.jci.org
VECs) synthesize ET-1 (3) and endothelial cells secrete ET-1 predominantly across their basolateral surfaces (4), making renal microvascular endothelium a possible contributor to the increase in renal interstitial fluid ET-1 content induced by dietary acid.

These studies tested the hypothesis that reduced extracellular $\mathrm{pH}$ stimulates ET-1 secretion by RMVECs. Primary cultures of human RMVECs were incubated with media of lower (acid) and higher (alkaline) $\mathrm{pH}$ compared with control. Media ET-1 accumulation was higher than control in RMVECs exposed to acid media but was not different in cells exposed to alkaline media. The data show that acid-stimulated ET-1 synthesis mediated the higher ET-1 secretion induced by lowered extracellular $\mathrm{pH}$ and suggest that this increased ET-1 synthesis requires de novo transcription. By contrast, ET-1 secretion was not different in identically treated human macrovascular (aortic) endothelial cells, showing that ET-1 secretion is more sensitive to reduced extracellular $\mathrm{pH}$ in RMVECs than in these macrovascular endothelial cells. The data describe a new environmental factor that modulates ET-1 secretion by microvascular endothelium and suggest a mechanism by which dietary acid might increase renal cortical ET-1 levels.

\section{Methods}

Endothelial cell cultures. Primary cultures of human glomerular endothelial cells (hereafter referred to as RMVECs) were obtained from kidneys harvested for transplantation but not transplanted because of technical or immunological reasons as described previously (5). Briefly, slices of cortex were separated from the medulla, minced with a scalpel, and pushed through a stainless steel $250-\mu \mathrm{m}$ screen. The cortical mash was collected in HBSS containing penicillin (100 $\mathrm{U} / \mathrm{ml})$, gentamicin $(25 \mu \mathrm{g} / \mathrm{ml})$, and streptomycin $(100 \mu \mathrm{g} / \mathrm{ml})$. The glomerular suspension was washed and centrifuged four times at $800 \mathrm{~g}$ until rendered blood free. The suspension was sequentially filtered through nylon sieves (Nitex) with pore sizes 210 and $150 \mu \mathrm{m}$ for adults or $100 \mu \mathrm{m}$ for children. Retained glomeruli were collected in a sterile cup, centrifuged twice at $800 \mathrm{~g}$ in HBSS containing antibiotics and resuspended in Waymouth MB 752/1 medium containing 2\% collagenase (Sigma Chemical Co., St. Louis, MO). The collagenasedigested glomeruli were centrifuged, washed, and resuspended in Waymouth's. Glomerular segments retained on 52- $\mu \mathrm{m}$ filter paper were collected in a sterile cup and plated in medium containing 200 $\mu \mathrm{g} / \mathrm{ml}$ endothelial cell growth factor, $100 \mu \mathrm{g} / \mathrm{ml}$ heparin, and $20 \%$ FBS. Cell identification as endothelial in origin was established by uptake of acetylated LDL, presence of Factor VIII-related antigen by indirect immunofluorescence, and uptake of phalloidin-actin in a peripheral location $(5,6)$. Cells were grown in $25-\mathrm{cm}^{2}$ tissue culture flasks (Corning Glass Works, Corning, NY) to fourth passage, then seeded into 6-well plates, grown to confluence in endothelial growth media (EGM; Clonetics, San Diego, CA), and studied in fifth passage. Because endotoxin stimulates endothelin release by vascular endothelial cells (7), media additives were carefully chosen for their low endotoxin content to minimize basal ET-1 secretion. Media endotoxin concentration measured using a QCL-1000 assay (Bio-Whittaker, Inc., Walkersville, MD) was consistently $<25 \mathrm{pg} / \mathrm{ml}$, a level below that necessary to increase endothelin release above control levels (7). 
Human aortic endothelial cells (AECs) were purchased from Clonetics. Cells were received in the fourth passage in $25-\mathrm{cm}^{2}$ tissue culture flasks, propagated in EGM (Clonetics) to fifth passage in 75$\mathrm{cm}^{2}$ tissue culture flasks, and then seeded into 6-well plates where they were grown to confluence and studied in the sixth passage.

After confluence was reached in the 6-well plates, both RMVECs and AECs were exposed to serum-free media for $24 \mathrm{~h}$. Then, media of both cell types were changed to serum-free media that contained no additional buffers or to serum-free media buffered to one of the three described pHs. It was this final media in which ET-1 concentration was measured.

Buffering of cell culture media to maintain assigned $\mathrm{pH}$. $\mathrm{pH}$ of standard EGM growth media equilibrated with $5 \% \mathrm{CO}_{2}$ at $37^{\circ} \mathrm{C}$ was $\sim 7.2$ and decreased to $\sim 7.0$ after $12 \mathrm{~h}$ of cell incubation (Table I). Because these are standard growth media used for vascular endothelial cells and because both RMVECs and AECs grew well and were morphologically healthy with these media, control media $\mathrm{pH}$ was assigned as 7.2. To examine effects of medium $\mathrm{pH}$ on cell ET-1 secretion, we used net differences from the selected control $\mathrm{pH}$ that could be reliably maintained in vitro and that might conceivably occur in vivo. Preliminary studies showed that control media $\mathrm{pH}$ as well as alkaline (7.4, created by adding $\mathrm{NaOH}$ ) and acid $(7.0$, created by adding $\mathrm{HCl}$ ) changes could be maintained for $12 \mathrm{~h}$ (see Table I) by combined addition of Hepes $(40 \mathrm{mM})$ and Tris $(30 \mathrm{mM})$. Consequently, control, alkaline, and acid media contained these concentrations of Hepes and Tris. To ensure that incubation media were fully equilibrated with $\mathrm{CO}_{2}$ at the start of the incubation period, all media were bubbled with $5 \% \mathrm{CO}_{2}$ gas in a sterile fashion before incubating with cells. ET-1 concentration ([ET-1]) was measured (see below) in media aliquots at $0,3,6$, and $12 \mathrm{~h}$. For cell-exposed media buffered to a given $\mathrm{pH}$, only those wells in which $\mathrm{pH}$ of the aliquot measured with a $\mathrm{pH}$ probe (model PHM146U; Lazar Research Labs, Los Angeles, CA) remained within $0.05 \mathrm{pH}$ units of the assigned value throughout the incubation were used for ET-1 determinations.

Endothelin measurement. Concentrations of ET-1 and big ET-1 were measured (8) using an RIA kit from Amersham Co. (Belmont, CA) in media and cell extracts. Before RIA, ET-1 and big ET-1 were extracted from media or cells by solid phase sorbent extraction with disposable columns (Sep-Pak C18; Millipore Corp., Milford MA) preconditioned with methanol, $\mathrm{H}_{2} \mathrm{O}$, and acetic acid as described $(1,8)$. The assays measure ET- 1 and big ET- 1 with a sensitivity of $0.4 \mathrm{pM}$. In vitro recoveries from media spiked with $\left[{ }^{125} \mathrm{I}\right] \mathrm{ET}-1$ and $\left[{ }^{125} \mathrm{I}\right]$ big ET-1 were 89 and $88 \%$, respectively. A $3.0-\mathrm{ml}$ initial media volume was added to each well of a 6-well plate from which an aliquot of $0.5 \mathrm{ml}$ was immediately and gently obtained for $\mathrm{pH}$ measurement and ET-1 and big ET-1 determination at time 0 . Subsequent $0.5-\mathrm{ml}$ aliquots were obtained at the described time intervals for the same determinations. ET-1 and big ET-1 concentrations for subsequent aliquots were corrected for a $2.5-\mathrm{ml}$ initial volume. Cell extracts were obtained by gently removing overlying culture media, rinsing the monolayer twice with PBS, then gently scraping cells from the wells in PBS containing aprotinin $(0.12 \mathrm{TIU} / \mathrm{ml})$ followed by sonication. The suspension was centrifuged for $5 \mathrm{~min}$ at $13,000 \mathrm{~g}$ and the supernatant was stored at $-70^{\circ} \mathrm{C}$ until assayed. Total protein in cell extracts was measured with the Lowry method using a BSA standard (9). The method measures ET-1 and big ET-1 both inside and attached to RMVECs.

ET-1 degradation was examined by measuring the decrease in concentration of exogenous ET-1 (i.e., ET-1 added to media before exposure to cells) exposed to RMVECs. Each well containing RMVECs and media with exogenous ET-1 was paired with a well containing RMVECs incubated with media without exogenous ET-1. Media aliquots were obtained for ET-1 concentration from each well of the pair at the time intervals described above. Recognizing that RMVECs will add ET-1 to overlying media with time, the concentration of exogenous ET-1 was estimated by subtracting ET-1 concentration of the media without exogenous ET-1 from that for the media with exogenous ET- 1 at the same time interval. The ET- 1 concentration differences between these well pairs comprise the data depicted in Table V.
Effect of media pH changes on cell membrane integrity. We examined cell membrane integrity in response to altered media $\mathrm{pH}$ by measuring cell and media LDH levels, calculated as NADH oxidation rate in the presence of sodium pyruvate (procedure No. 228-UV; Sigma Diagnostics, St. Louis, MO). RMVECs grown to confluence in 6-well plates with standard EGM were exposed to serum-free EGM for $24 \mathrm{~h}$, then to standard serum-free EGM or to serum-free EGM buffered to one of the three experimental pHs. Serial LDH concentrations were measured in media exposed to cells up to $12 \mathrm{~h}$. To determine cell-associated LDH activity, $1 \mathrm{ml}$ of $0.2 \mathrm{M}$ potassium phosphate-1 mM EDTA ( $\mathrm{pH}$ 7.5) was added and the cell monolayer was dispersed mechanically. After lysis with $10 \%$ Triton X-100, cells were centrifuged at $13,000 \mathrm{~g}$ for $10 \mathrm{~min}$ and an aliquot of the supernatant was analyzed. Media LDH release was calculated as fraction of medium LDH activity relative to total (medium + cell associated LDH) activity.

Reagents. Actinomycin D, Triton X-100, and fetuin were obtained from Sigma Chemical Co., and endothelial growth supplement was from Collaborative Research Inc. (Bedford, MA). Cell culture reagents including Waymouth's media were obtained from Gibco Laboratories (Grand Island, NY), and FBS was from Hyclone Laboratories Inc. (Logan, UT).

Statistical analysis. Results are means \pm SE. Statistical significance was determined using ANOVA when comparing more than two means. The Bonferroni method was used for $t$ test comparison of means $(P<0.05)$ for multiple different comparisons of the same parameter among the three groups. Student's $t$ test for paired observations was used where appropriate.

\section{Results}

Change in media $\mathrm{pH}$ when incubated with cells. $\mathrm{pH}$ of standard EGM media contained in 6-well plates and incubated in 5\% $\mathrm{CO}_{2}$ at $37^{\circ} \mathrm{C}$ for $12 \mathrm{~h}$ without cells was not different at the end (7.18 $\pm 0.02, n=6$ wells) of the incubation period from that at the start $(7.21 \pm 0.02, n=6$ wells, $P=0.31)$. By contrast, media $\mathrm{pH}$ decreased progressively during $12 \mathrm{~h}$ of exposure to RMVECs as shown in Table I. The $\mathrm{pH}$ of media exposed to AECs for $12 \mathrm{~h}$ decreased similarly (data not shown). Table I also shows that the Hepes/Tris buffer combination maintained assigned $\mathrm{pH}$ differences for the 12-h incubation.

Effects of extracellular pH on media ET-1 accumulation and on cell integrity. Table II depicts accumulation of ET-1 in media overlying a confluent monolayer of RMVECs. Media [ET-1] was lower at 6 and $12 \mathrm{~h}$ when the decrease in media $\mathrm{pH}$ was prevented with added buffers. There were no differences in [ET-1] among buffered media incubated with RMVECs up to $6 \mathrm{~h}$. By contrast, $12 \mathrm{~h}$ [ET-1] in acid (7.0) media was higher

Table I. Change in Media pH during Incubation with RMVECs in $5 \% \mathrm{CO}_{2}$ and at $37^{\circ} \mathrm{C}$

\begin{tabular}{|c|c|c|c|c|}
\hline & $0 \mathrm{~h}$ & $3 \mathrm{~h}$ & $6 \mathrm{~h}$ & $12 \mathrm{~h}$ \\
\hline $\begin{array}{l}\text { EGM (no added } \\
\text { buffer) }\end{array}$ & $\begin{array}{c}7.21 \pm 0.007 \\
(n=4)\end{array}$ & $\begin{array}{c}7.18 \pm 0.006 \\
(n=4)\end{array}$ & $\begin{array}{c}7.12 \pm 0.009 \\
(n=4)\end{array}$ & $\begin{array}{c}7.01 \pm 0.009 \\
(n=4)\end{array}$ \\
\hline $\begin{array}{l}\text { EGM (buffered } \\
\text { to } 7.2 \text { ) }\end{array}$ & $\begin{array}{c}7.23 \pm 0.005 \\
(n=6)\end{array}$ & $\begin{array}{c}7.21 \pm 0.006 \\
(n=6)\end{array}$ & $\begin{array}{l}7.19 \pm 0.005 \\
(n=6)\end{array}$ & $\begin{array}{c}7.18 \pm 0.007 \\
(n=6)\end{array}$ \\
\hline $\begin{array}{l}\text { EGM (buffered } \\
\text { to } 7.4 \text { ) }\end{array}$ & $\begin{array}{c}7.41 \pm 0.006 \\
(n=6)\end{array}$ & $\begin{array}{c}7.37 \pm 0.005 \\
(n=6)\end{array}$ & $\begin{array}{c}7.35 \pm 0.007 \\
(n=6)\end{array}$ & $\begin{array}{c}7.33 \pm 0.007 \\
(n=6)\end{array}$ \\
\hline $\begin{array}{l}\text { EGM (buffered } \\
\text { to } 7.0 \text { ) }\end{array}$ & $\begin{array}{c}7.00 \pm 0.008 \\
(n=6)\end{array}$ & $\begin{array}{c}7.01 \pm 0.006 \\
(n=6)\end{array}$ & $\begin{array}{c}7.02 \pm 0.004 \\
(n=6)\end{array}$ & $\begin{array}{c}6.98 \pm 0.006 \\
(n=6)\end{array}$ \\
\hline
\end{tabular}

Values are means \pm SE, $n=$ number of wells. 
Table II. Effect of Extracellular pH on ET-1 Concentration $(p M)$ in Media Incubated with RMVECs

\begin{tabular}{ccccc}
\hline & $0 \mathrm{~h}$ & 03 & $6 \mathrm{~h}$ & $12 \mathrm{~h}$ \\
\hline EGM (no added & $11.1 \pm 7.9$ & $23.5 \pm 3.8$ & $77.0 \pm 8.7$ & $212.3 \pm 24.4$ \\
$\quad$ buffer) & $(n=4)$ & $(n=4)$ & $(n=4)$ & $(n=4)$ \\
EGM (buffered & $5.7 \pm 1.8$ & $16.3 \pm 4.8$ & $19.9 \pm 7.4^{*}$ & $64.6 \pm 9.6^{*}$ \\
$\quad$ to 7.2) & $(n=7)$ & $(n=7)$ & $(n=5)$ & $(n=5)$ \\
EGM (buffered & $3.4 \pm 1.1$ & $15.0 \pm 6.7$ & $13.8 \pm 5.0$ & $56.6 \pm 25.1^{*}$ \\
$\quad$ to 7.4) & $(n=5)$ & $(n=5)$ & $(n=4)$ & $(n=4)$ \\
EGM (buffered & $6.3 \pm 1.8$ & $15.1 \pm 6.7$ & $30.5 \pm 4.7$ & $170.0 \pm 17.1^{\ddagger}$ \\
to 7.0) & $(n=14)$ & $(n=14)$ & $(n=14)$ & $(n=11)$ \\
& & & & \\
\hline
\end{tabular}

Values are means \pm SE, $n=$ number of wells. ${ }^{*} P<0.05$ vs. EGM, no added buffer. ${ }^{\ddagger} P<0.05$ vs. EGM buffered to 7.2.

than control (7.2) but [ET-1] in alkaline (7.4) media was not different from control. Because higher [ET-1] in acid media might be due to $\mathrm{pH}$-induced lysis of RMVECs, cell integrity was examined after exposure to the unbuffered and the three buffered media. First, there were no morphological differences among cells exposed to unbuffered and buffered control media, nor were there differences among buffered control, acid, and alkaline media by phase microscopy. Second, Table III shows that media $[\mathrm{LDH}]$ and $\mathrm{LDH}$ release (medium/total LDH activity) was not different among RMVECs incubated in unbuffered and the three buffered media. Thus, increased ET-1 accumulation in media exposed to RMVECs induced by lowered extracellular $\mathrm{pH}$ is not due to $\mathrm{pH}$-induced cell lysis.

Effects of lowered extracellular pH on ET-1 degradation. Increased ET-1 accumulation in media of RMVECs induced by lowered extracellular $\mathrm{pH}$ might be due to reduced ET-1 degradation after cellular release, increased release of preformed ET-1 from cells, increased ET-1 synthesis, or to some combination of these mechanisms. We tested the hypothesis that increased ET-1 accumulation in the media of RMVECs induced by lowered extracellular $\mathrm{pH}$ is due to an acid-stimulated decrease in ET-1 degradation with unchanged cellular release and rate of ET- 1 synthesis. We reasoned that if this hypothesis were true, media concentration of exogenously added ET-1 exposed to RMVECs should decrease at a slower rate in

Table III. Effect of Extracellular pH on Release of LDH into Media by RMVECs

\begin{tabular}{ccccc}
\hline & \multicolumn{4}{c}{ LDH (U/liter) } \\
\cline { 2 - 5 } & $0 \mathrm{~h}$ & $3 \mathrm{~h}$ & $6 \mathrm{~h}$ & $12 \mathrm{~h}$ \\
\hline EGM (no added & $1.5 \pm 0.2$ & $1.8 \pm 0.2$ & $2.4 \pm 0.3$ & $2.7 \pm 0.3$ \\
buffer) $(n=4)$ & $(2.1)$ & $(2.4)$ & $(3.6)$ & $(3.8)$ \\
EGM (buffered & $1.7 \pm 0.2$ & $1.6 \pm 0.2$ & $1.8 \pm 0.2$ & $1.9 \pm 0.2$ \\
to 7.2) $(n=4)$ & $(2.2)$ & $(2.0)$ & $(2.1)$ & $(2.3)$ \\
EGM (buffered & $1.9 \pm 0.2$ & $2.2 \pm 0.3$ & $2.1 \pm 0.2$ & $2.4 \pm 0.3$ \\
to 7.4) $(n=4)$ & $(2.0)$ & $(2.2)$ & $(2.2)$ & $(2.5)$ \\
EGM (buffered & $1.9 \pm 0.2$ & $2.3 \pm 0.2$ & $2.5 \pm 0.2$ & $2.7 \pm 0.3$ \\
to 7.0) $(n=4)$ & $(2.0)$ & $(2.2)$ & $(2.4)$ & $(2.9)$ \\
& & & & \\
\hline
\end{tabular}

Values are means \pm SE, $n=$ number of wells. Data in parentheses are the ratio of medium LDH to total (medium + cell-associated) activity expressed as a percentage, the assessment of LDH release.
Table IV. Effect of Extracellular pH on Stability of ET-1 Concentration (pM) in Media Not Exposed to Cells and Incubated in $5 \% \mathrm{CO}_{2}$ at $37^{\circ} \mathrm{C}$

\begin{tabular}{|c|c|c|c|c|}
\hline & $0 \mathrm{~h}$ & $3 \mathrm{~h}$ & $6 \mathrm{~h}$ & $12 \mathrm{~h}$ \\
\hline $\begin{array}{l}\text { EGM (buffered } \\
\text { to } 7.2 \text { ) }\end{array}$ & $\begin{array}{c}190.1 \pm 4.5 \\
(n=6)\end{array}$ & $\begin{array}{c}181.4 \pm 11.7 \\
\quad(n=6)\end{array}$ & $\begin{array}{c}178.0 \pm 14.4 \\
(n=6)\end{array}$ & $\begin{array}{c}171.4 \pm 12.1 \\
(n=5)\end{array}$ \\
\hline $\begin{array}{l}\text { EGM (buffered } \\
\text { to } 7.4 \text { ) }\end{array}$ & $\begin{array}{c}188.3 \pm 6.7 \\
(n=6)\end{array}$ & $\begin{array}{c}183.6 \pm 11.9 \\
(n=5)\end{array}$ & $\begin{array}{c}175.9 \pm 13.3 \\
(n=5)\end{array}$ & $\begin{array}{c}169.5 \pm 12.3 \\
(n=4)\end{array}$ \\
\hline $\begin{array}{l}\text { EGM (buffered } \\
\text { to } 7.0 \text { ) }\end{array}$ & $\begin{array}{c}192.5 \pm 5.9 \\
(n=6)\end{array}$ & $\begin{array}{c}187.2 \pm 13.0 \\
\quad(n=6)\end{array}$ & $\begin{array}{c}174.8 \pm 12.6 \\
(n=6)\end{array}$ & $\begin{array}{c}163.7 \pm 8.9 \\
(n=6)\end{array}$ \\
\hline
\end{tabular}

Values are means \pm SE, $n=$ number of wells.

acid compared with control media. First, Table IV shows that when media containing ET-1 at a concentration comparable to that for acid-incubated RMVECs was incubated as described for $12 \mathrm{~h}$ without cells, [ET-1] was not different among buffered media up to $12 \mathrm{~h}$. Additionally, Table $\mathrm{V}$ shows that the concentration of exogenous ET-1 fell at a similar rate and to a similar 12-h level when buffered media were incubated with RMVECs. Thus, increased ET-1 secretion induced by lowered extracellular $\mathrm{pH}$ is not due to reduced ET-1 degradation after release from RMVECs.

Effect of extracellular pH on cell-associated ET-1. Next, we tested the hypothesis that increased media ET-1 accumulation induced by lowered extracellular $\mathrm{pH}$ is due to augmented release of preformed ET-1 from RMVECs with unchanged rate of ET-1 synthesis. If the hypothesis were true, RMVEC cellassociated ET-1 should be lower in cells incubated with the acid (7.0) compared with control (7.2) media. Instead, Fig. 1 shows that cell-associated ET-1 was higher for RMVECs after $12 \mathrm{~h}$ in acid compared with control buffered media (106.6 \pm 16.0 vs. $43.1 \pm 4.7 \mathrm{fM} / \mathrm{mg}$ cell protein, respectively, $n=$ 3 wells each, $P<0.04)$, but that for RMVECs incubated in alkaline media $(50.5 \pm 5.4 \mathrm{fM} / \mathrm{mg}$ cell protein, $n=3$ wells) was not different from control. Thus, higher media ET-1 accumulation induced by lowered extracellular $\mathrm{pH}$ is not due to increased ET-1 release with unchanged ET-1 synthesis and degradation.

Effect of inhibited ET-1 synthesis on increased media ET-1 accumulation induced by lowered media $\mathrm{pH}$. The following experiments investigated if increased ET-1 accumulation in me-

Table V. Effect of Extracellular pH on Stability of ET-1 Concentration (pM) in Media Exposed to RMVECs and Incubated in $5 \% \mathrm{CO}_{2}$ at $37^{\circ} \mathrm{C}$

\begin{tabular}{|c|c|c|c|c|}
\hline & $0 \mathrm{~h}$ & $3 \mathrm{~h}$ & $6 \mathrm{~h}$ & $12 \mathrm{~h}$ \\
\hline $\begin{array}{l}\text { EGM (buffered } \\
\text { to } 7.2 \text { ) }\end{array}$ & $\begin{array}{r}181.1 \pm 10.1 \\
(n=12)\end{array}$ & $\begin{array}{r}145.1 \pm 14.3 \\
\quad(n=11)\end{array}$ & $\begin{array}{c}129.0 \pm 13.6 \\
(n=9)\end{array}$ & $\begin{array}{c}107.3 \pm 11.7 \\
(n=8)\end{array}$ \\
\hline $\begin{array}{l}\text { EGM (buffered } \\
\text { to } 7.4 \text { ) }\end{array}$ & $\begin{array}{r}188.9 \pm 6.4 \\
(n=12)\end{array}$ & $\begin{array}{r}155.6 \pm 16.4 \\
(n=10)\end{array}$ & $\begin{array}{c}136.5 \pm 15.0 \\
(n=7)\end{array}$ & $\begin{array}{c}99.4 \pm 10.5 \\
(n=6)\end{array}$ \\
\hline $\begin{array}{l}\text { EGM (buffered } \\
\text { to } 7.0 \text { ) }\end{array}$ & $\begin{array}{r}198.1 \pm 5.5 \\
(n=12)\end{array}$ & $\begin{array}{c}148.1 \pm 17.0 \\
(n=12)\end{array}$ & $\begin{array}{r}125.5 \pm 13.3 \\
(n=11)\end{array}$ & $\begin{array}{r}101.2 \pm 11.5 \\
(n=11)\end{array}$ \\
\hline
\end{tabular}

Values are means \pm SE, $n=$ number of wells. Each value was corrected for the ET-1 concentration of a paired well without added ET-1 (see Methods). 


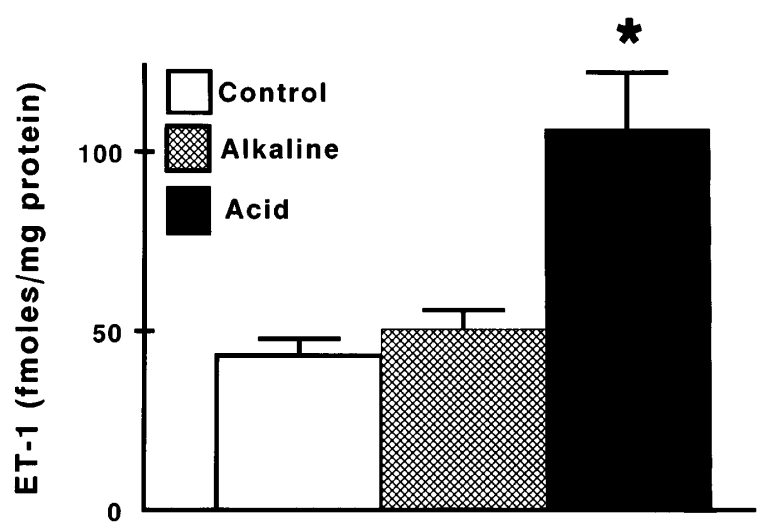

Figure 1. Cell-associated ET-1 concentrations in RMVECs after $12 \mathrm{~h}$ of incubation in control (7.2), alkaline (7.4), and acid (7.0) media. $* P<0.05$ vs. control.

dia overlying RMVECs is due to augmented ET-1 synthesis. We first tested the hypothesis that increased media accumulation of ET-1 induced by lowered media $\mathrm{pH}$ is mediated by stimulated conversion of big ET-1 to ET-1 with unchanged rate of transcription and translation. If this hypothesis were true, cell-associated and/or media concentrations of big ET-1 should be lower for RMVECs incubated with acid media. Fig. 2 shows that the concentration of big ET-1 was not lower in acid-exposed compared with control RMVECs whether associated with cells $(73.4 \pm 8.9$ vs. $73.4 \pm 15.2 \mathrm{fM} / \mathrm{mg}$ cell protein, respectively, $n=3$ wells, $P=$ NS) or in the media (34.7 \pm 13.2 vs. $8.7 \pm 1.0 \mathrm{pM}$, respectively, $n=3$ wells, $P=0.12$ ). Thus, increased media ET-1 accumulation induced by lowered extracellular $\mathrm{pH}$ is not due to stimulated conversion of big ET-1 to ET-1 with unchanged synthesis of big ET-1.

Altogether, the data are consistent with the hypothesis that increased media accumulation of ET- 1 induced by lowered media $\mathrm{pH}$ is due to an acid-stimulated increase in ET-1 synthesis mediated by a mechanism proximal to big ET-1 formation. Increased ET-1 synthesis might be mediated by stimulated transcription with subsequent translation of newly formed endothelin mRNA or, alternatively, to stimulated translation of preformed endothelin mRNA. We tested the latter hypothesis by measuring media ET-1 accumulation from RMVECs exposed to each of the three media containing $1 \mu \mathrm{g} / \mathrm{ml}$ actinomycin D. If this hypothesis were true, inhibition of transcription would not prevent the increase in media ET-1 accumulation

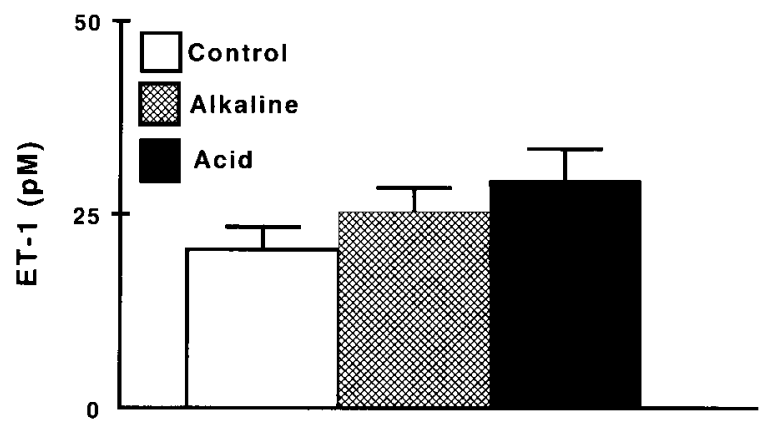

Figure 3. Media ET-1 concentrations in RMVECs after $12 \mathrm{~h}$ of incubation in control (7.2), alkaline (7.4), and acid (7.0) media in the presence of actinomycin D $(1 \mu \mathrm{g} / \mathrm{ml})$.

induced by lowered media $\mathrm{pH}$. Fig. 3 shows that in the presence of actinomycin D, 12-h media ET-1 accumulation was not different among control, alkaline, or acid groups (20.5 \pm 2.9 , $25.4 \pm 3.0$, and $29.5 \pm 4.0 \mathrm{pM}, P=\mathrm{NS}$ ). Thus, transcription inhibition in RMVECs prevented increased media ET-1 accumulation induced by lowered media $\mathrm{pH}$, suggesting that this phenomenon requires de novo transcription. Altogether, the data show that acid-stimulated ET-1 secretion by RMVECs is due to increased ET-1 synthesis and support that the increased synthesis is mediated in part by de novo transcription.

pH influence on ET-1 secretion in RMVECs versus AECs. To determine if acid-stimulated ET-1 secretion is characteristic of all vascular endothelial cells, the effect of identical $\mathrm{pH}$ changes on ET-1 accumulation in media overlying monolayers of AECs was examined. Fig. 4 shows that ET-1 accumulation was not different in AECs exposed to acid (139.2 $\pm 18.5 \mathrm{pM})$, alkaline $(205.9 \pm 25.3 \mathrm{pM})$, or control $(166.5 \pm 18.1 \mathrm{pM})$ media for $12 \mathrm{~h}$. Thus, acid-stimulated ET-1 secretion is characteristic of RMVECs but not AECs.

\section{Discussion}

Increased renal cortical ET-1 content induced by dietary acid (1) potentially has both physiologic and pathophysiologic significance. Endogenous endothelins mediate increased distal tubule acidification induced by dietary acid (1) and exogenous ET-1 infusion increases distal tubule acidification (2). These studies support that endothelins play a physiologic role in renal acidification. On the other hand, ET-1 production in-

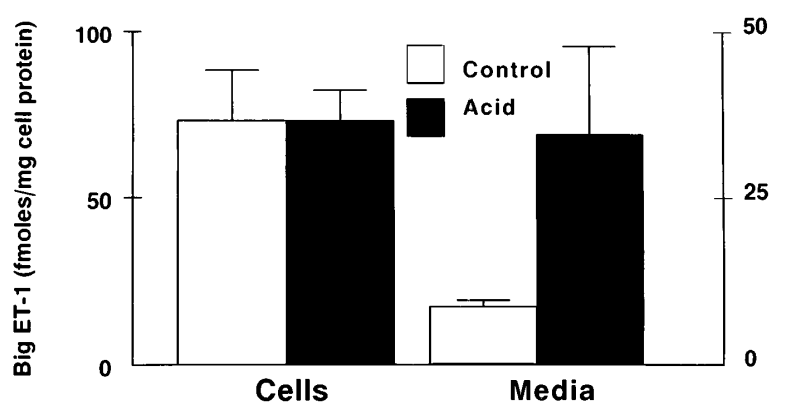

Figure 2. Cell-associated and media big ET-1 concentrations in RMVECs after $12 \mathrm{~h}$ of incubation in control (7.2) and acid (7.0) media.

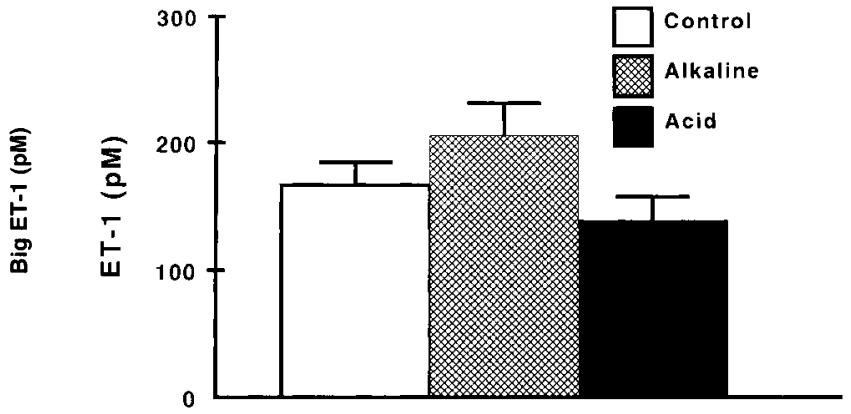

Figure 4. Media ET-1 concentrations in AECs after $12 \mathrm{~h}$ of incubation in control (7.2), alkaline (7.4), and acid (7.0) media. 
creases with reduced renal mass (8) and ET-1 increases renal fibronectin and collagen production (10). These latter studies are consistent with an endothelin role in the pathophysiology of progressive renal sclerosis associated with reduced renal mass. Thus, $\mathrm{pH}$ and possibly other environmental factors might affect renal function through their effects on renal endothelin production. Increased renal cortical acid content induced by dietary acid (2) might be such an environmental factor that increases renal cortical ET-1 content. In general, endothelins are synthesized, exert their effects, and are degraded locally (11) so that locally produced endothelins likely have the greatest influence on renal function. Renal ET-1 might derive from renal epithelium (12) and/or microvascular endothelium (3). These studies tested the hypothesis that reduced extracellular $\mathrm{pH}$ increases ET-1 secretion by human RMVECs. The data show that reduced $\mathrm{pH}$ increases ET- 1 secretion by these cells and suggest that the increased secretion is mediated by stimulated ET- 1 synthesis.

ET-1 secretion is regulated predominantly by transcription and is modulated by various hormones and physical forces (11, 13). Only small amounts of ET-1 are stored in vascular endothelial cells and most are released after synthesis $(14,15)$. These studies exclude acid-induced decreased ET-1 degradation, increased release of preformed ET-1 from cellular compartments, and accelerated conversion of big ET-1 to ET-1 as mechanisms of increased ET-1 secretion caused by reduced extracellular $\mathrm{pH}$. The studies are most consistent with an acidinduced increase in ET-1 synthesis by RMVECs mediated by de novo transcription. Similar to these studies, other studies show effects of extracellular fluid composition on cellular ET-1 secretion. Media osmolality modulates ET-1 secretion by cultured collecting duct cells and the response of ET-1 secretion by these cells to AVP (16). These investigators propose that ET-1 modulates water homeostasis in vivo in a paracrine fashion (16). Similarly, this and previous studies suggest a model in which locally produced ET-1 increases distal nephron acidification in a paracrine and/or possibly an autocrine fashion. In the proposed cascade, increased distal tubule acidification induced by dietary acid (17) is mediated by increased renal cortical acid content associated with this dietary maneuver (2), leading to higher interstitial fluid levels of ET-1 (1), the latter directly increasing distal tubule acidification (18). This model is supported by renal anatomy in which renal interstitial fluid bathes both distal tubule epithelium and vascular endothelium of the renal cortex (19), possibly allowing paracrine and/or autocrine communication between these cell types.

The cellular source of ET-1 addition to cortical renal interstitial fluid (1) was not clear in these previous studies. Considering cortical sources of ET-1, cortical collecting duct cells have endothelin-like immunoreactivity (20), and proximal as well as cortical collecting tubule cells synthesize ET-1 (21). Additionally, RMVEC contain endothelin converting enzyme $(22,23)$, the enzyme responsible for converting big ET-1 to ET-1. The enzyme is primarily in the plasma membrane of these cells $(22,23)$ and faces outward, making it an ectoenzyme (22). This anatomical arrangement facilitates ET-1 release to renal interstitial fluid, permitting it to modulate function of adjacent renal epithelial cells. Nevertheless, the highest renal ET-1 levels are in the inner medulla, contributed in part by inner medullary collecting duct cells (21). Whether ET-1 secretion by cells of this part of the kidney are influenced by extracellular $\mathrm{pH}$ awaits further study.
The mechanism(s) by which lowered extracellular $\mathrm{pH}$ increases ET-1 secretion by RMVECs was not determined in these studies. Because media $\mathrm{pH}$ was lowered with unchanged $\mathrm{PCO}_{2}$ (see Methods), media $\mathrm{HCO}_{3}$ was also lower, possibly influencing ET-1 secretion independent of $\mathrm{pH}$. The cell signaling cascade(s) that mediate ET-1 secretion are incompletely understood (13). Many substances increase ET-1 secretion by vascular endothelial cells (24) and by possibly different intracellular mechanisms. Tyrosine kinase mediates insulin-induced ET-1 secretion in vascular endothelial cells (25) and protein kinase $\mathrm{C}$ mediates ET-1 secretion stimulated by angiotensin II (24). Whether cellular kinases mediate increased ET-1 secretion induced by lowered extracellular $\mathrm{pH}$ awaits determination by future studies.

The degree of extracellular $\mathrm{pH}$ reduction that increased ET-1 secretion by RMVECs had no effect on ET-1 secretion by AECs for reason(s) that are not apparent from the data of the present studies. Basal ET-1 secretion was higher in AECs and larger $\mathrm{pH}$ changes might be necessary to alter ET-1 secretion in these macrovascular endothelial cells. On the other hand, differences in $\mathrm{pH}$ sensitivity of ET-1 secretion between the cell types might relate to differences in the basal $\mathrm{pH}$ to which the two cell types are exposed in vivo. Although systemic arterial $\mathrm{pH}$ to which the macrovascular endothelium is exposed in vivo is $\sim 7.4, \mathrm{pH}$ of the renal cortex of control animals is somewhat more acid than the systemic value, being 7.25 in studies from our laboratory (3) and 7.27 in those from other laboratories (26). Thus, the control $\mathrm{pH}$ of 7.2 in the present studies (selected for the reasons detailed in Methods) was closer to the basal in vivo value of RMVECs than AECs. Nevertheless, ET-1 secretion in AECs did not decrease compared with the "control" $\mathrm{pH}$ of 7.2 when media $\mathrm{pH}$ was increased to the theoretical basal value of 7.4, nor did it increase when $\mathrm{pH}$ was decreased $0.4 \mathrm{pH}$ units from the theoretical basal extracellular $\mathrm{pH}$ to 7.0. Although other in vivo factors might account for the described differences in basal ET-1 secretion between the two types of vascular endothelium and their sensitivity to changes in extracellular $\mathrm{pH}$, the data nevertheless show greater acid sensitivity of ET-1 secretion in RMVECs compared with AECs under the identical in vitro conditions of the present studies in which extracellular $\mathrm{pH}$ was changed within a physiologic range.

In summary, these studies show that reduced extracellular $\mathrm{pH}$ increases ET-1 secretion by RMVECs and suggest that this phenomenon is mediated by stimulated ET-1 synthesis. By contrast, ET-1 secretion was not different among human macrovascular (aortic) endothelial cells exposed to the same acid extracellular environment, indicating that acid-stimulated ET-1 secretion is not characteristic of all vascular endothelial cells. The data identify a new environmental factor that modulates ET-1 secretion by renal microvascular endothelium and suggest a mechanism by which a systemic acid challenge might increase renal ET-1 secretion.

\section{Acknowledgments}

We are grateful to Mrs. Geraldine Tasby and Ms. Cathy Hudson for expert technical assistance and to Neil A. Kurtzman for continued support.

This work was supported by funds from National Institutes of Health grant 5-RO1-DK 36199-10 (N.A. Kurtzman, P.I.) and from the Texas Tech University Health Sciences Center. 


\section{References}

1. Wesson, D.E. 1997. Endogenous endothelins mediate increased distal tubule acidification induced by dietary acid in rats. J. Clin. Invest. 99:2203-2211.

2. Wesson, D.E. 1998. Dietary acid increases blood and renal cortical acid content in rats. Am J. Physiol. 274 (Renal Physiol. 43):F97-F103.

3. Ballerman, B., and P.A. Marsden. 1991. Endothelium-derived vasoactive mediators and renal glomerular function. Clin. Invest. Med. 14:508-517.

4. Wagner, O.F., G. Christ, J. Wojta, H. Vierhapper, S. Parzer, P.J. Nowotny, B. Schneider, W. Waldhausl, and B. Binder. 1992. Polar secretion of endothelin-1 by cultured endothelial cells. J. Biol. Chem. 267:16066-16068.

5. Green, D.F., K. Hwang, U.S. Ryan, and J.J. Bourgoignie. 1992. Culture of human and baboon capillary endothelial cells. Kidney Int. 41:1506-1516.

6. Green, D.F., C. Martinez, R. Laskey, and C.O. O'Neill. 1994. Autocrine synthesis of nitric oxide by cultured human glomerular endothelial cell monolayers. J. Am. Soc. Nephrol. 5:579-587.

7. Sugiura, M., T. Inagami, and V. Kon. 1989. Endotoxin stimulates endothelin-release in vivo and in vitro as determined by radioimmunoassay. Biochem. Biophys. Res. Commun. 161:1220-1227.

8. Benigni, A., N. Perico, F. Gaspari, C. Zoja, L. Bellizzi, M. Gabanelli, and G. Remuzzi. 1991. Increased renal endothelin production in rats with reduced renal mass. Am. J. Physiol. 260(Renal Fluid Electrolyte Physiol. 29):F331-F339.

9. Lowry, O.H., N.J. Rosebrough, A.L. Farr, and R.J. Randall. 1951. Protein measurement with Folin phenol reagent. J. Biol. Chem. 193:265-275.

10. Ruiz-Ortega, M., D. Gomez-Garre, R. Alcazar, I. Palacios, C. Bustos, S. Gonzalez, J.J. Plaza, E. Gonzalez, and J. Egido. 1994. Involvement of angiotensin II and endothelin in matrix protein production and renal sclerosis. J. $\mathrm{Hy}$ pertens. 12(Suppl. 4):S51-S58.

11. Kohan, D.E. 1997. Endothelins in the normal and diseased kidney. Am. J. Kidney Dis. 29:2-26.

12. Ujiie, K., Y. Terada, H. Nonoguchi, M. Shinohara, K. Tomita, and F. Marumo. 1992. Messenger RNA expression and synthesis of endothelin-1 along rat nephron segments. J. Clin. Invest. 90:1043-1048.

13. Marsen, T.A., H. Schramek, and M.J. Dunn. 1994. Renal actions of endothelin: linking cellular signaling pathways to kidney disease. Kidney Int. 45: 336-344.

14. Brandt, R., D.M. Heublein, M.T. Mattingly, M.R. Pittelkow, and J.C.
Burnett. 1995. Presence and secretion of atrial natriuretic peptide from cultured human aortic endothelial cells. Am. J. Physiol. 268(Heart Circ. Physiol. 37): H921-H925.

15. Clozel, M., B.-M. Loffler, V. Breu, L. Hilfiger, J.-P. Maire, and B. Butscha. 1993. Downregulation of endothelin receptors by autocrine production of endothelin-1. Am. J. Physiol. 256(Cell Physiol. 34):C188-C192.

16. Kohan, D.E., and E. Padilla. 1993. Osmolar regulation of endothelin-1 production by rat inner medullary collecting duct. J. Clin. Invest. 91:1235-1240.

17. Wesson, D.E. 1996. Reduced bicarbonate secretion mediates increased distal tubule acidification induced by dietary acid. Am. J. Physiol. 271(Renal Fluid Electrolyte Physiol. 40):F670-F678.

18. Wesson, D.E., and G.M. Dolson. 1997. Endothelin-1 increases rat distal tubule acidification in vivo. Am. J. Physiol. 273(Renal Physiol. 42):F586-F594.

19. Kriz, W., and B. Kaissling. 1992. Structural organization of the mammalian kidney. In The Kidney. Physiology and Pathophysiology. D. Seldin and G. Giebisch, editors. Raven Press, New York. 207.

20. Wilkes, B., M. Susin, P.F. Mento, C.M. Macica, E.P. Giradi, E. Boss, and E.P. Nord. 1991. Localization of endothelin-like reactivity in rat kidneys. Am. J. Physiol. 260(Renal Fluid Electrolyte Physiol. 29):F913-F920.

21. Kohan, D. 1991. Endothelin synthesis by rabbit renal tubule cells. Am. J. Physiol. 261(Renal Fluid Electrolyte Physiol. 30):F221-F226.

22. Emoto, E., and M. Yanagisawa. 1995. Endothelin-converting enzyme-2 is a membrane-bound, phosphoramidon-sensitive metalloprotease with acidic pH optimum. J. Biol. Chem. 270:15262-15268.

23. Takahashi, M., K. Fukada, K. Shimada, K. Barnes, A.J. Turner, M. Ikeda, H. Koike, Y. Yamamoto, and K. Tanzawa. 1995. Localization of rat endothelin-converting enzyme to vascular endothelial cells and some secretory cells. Biochem. J. 311:657-665

24. Emori, T., Y. Hirata, K. Ohta, K. Kanno, S. Eguchi, T. Imai, M. Shichiri, and F. Marumo. 1991. Cellular mechanism of endothelin-1 release by angiotensin and vasopressin. Hypertension. 18:165-170.

25. Ferri, C., V. Pittoni, A. Piccoli, O. Laurenti, M.R. Cassone, C. Bellini, G. Properzi, G. Valesini, G. DeMattia, and A. Santucci. 1995. Insulin stimulates endothelin secretion from human endothelial cells and modulates its circulating levels in vivo. J. Clin. Endocrinol. Metab. 80:829-835.

26. DuBose, T.D., L.R. Pucacco, M.S. Lucci, and N.W. Carter. 1979. Micropuncture determination of $\mathrm{pH}, \mathrm{PCO}_{2}$, and total $\mathrm{CO}_{2}$ concentration of the rat renal cortex. J. Clin. Invest. 64:476-482. 